\title{
Pendampingan Aplikasi Alat Pelindung Diri pada Pemulung Sampah di Kelurahan Langkai Kota Palangka Raya
}

\author{
Assistance in the Application of Personal Protective Equipment in Waste Scavengers in the \\ City of Langkai, Palangkaraya City
}

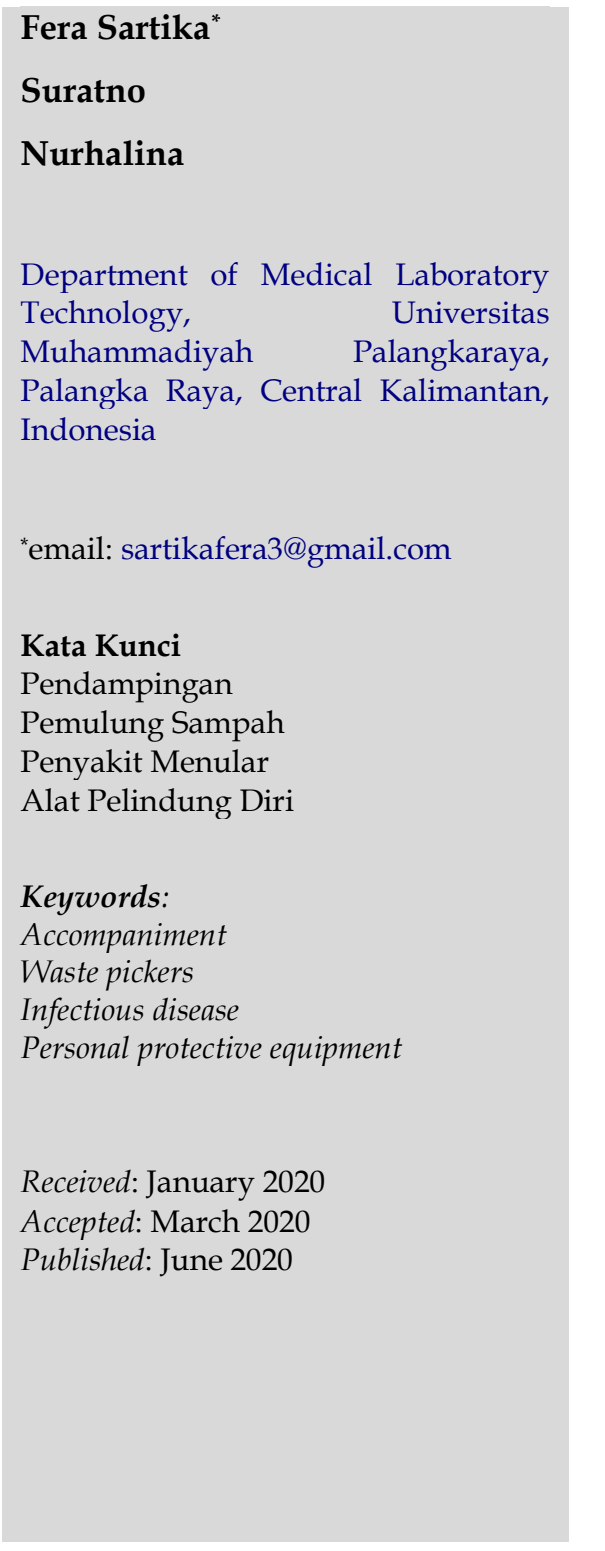

\begin{abstract}
Abstrak
Para pemulung sampah sangat beresiko terkena penyakit yang dapat ditularkan melalui sampah, sehingga diperlukan Alat Pelindung Diri (APD) sebagai perangkat alat yang dipakai oleh tenaga kerja untuk melindungi dirinya terhadap kemungkinan adanya potensi bahaya serta kecelakaan kerja.Meskipun belum terdapat data yang pasti adanya kecelakaan atau penyakit akibat kerja di TPS atau TPA, namun risiko adanya gangguan kesehatan atau penyebaran penyakit karena paparan berbagai jenis sampah sangat mungkin terjadi. Begitu juga dengan pemulung sampah yang berada di Tempat Penampungan Sementara (TPS) di Kelurahan Langkai Kota Palangka Raya. Tujuan kegiatan pengabdian kepada masyarakat ini untuk memberikan pendampingan dalam pengaplikasian APD dengan memberikan edukasi serta sosialisai tentang kemungkinan adanya potensi bahaya serta kecelakaan kerja sebagai pemulung sampah dan resiko terpapar penyakit yang dapat ditularkan melalui sampah, pelatihan dan demonstrasi tentang penggunaan APD saat bekerja serta penyerahan seperangkat alat APD kepada para pemulung. Kegiatan pengabdian kepada masyarakat dilakukan terhadap 39 pemulung yang tersebar di TPS-TPS yang berada di Kelurahan Langkai Kota Palangka Raya.
\end{abstract}

\begin{abstract}
Waste pickers are the riskiest group for disease transmission through waste, so have Personal Protective Equipment (PPE) is needed as a tool used by workers to protect themselves against potential dangers and work accidents. Although there are no definitive data on the existence of accidents or occupational diseases in TPS or TPA, the risk of health problems or the spread of disease due to exposure to various types of waste is very possible. Likewise with the waste pickers who are in the Temporary Shelter (TPS) in the Kelurahan Langkai City of Palangka Raya. The purpose of community service activities is to assist in the application of PPE by providing education and socialization about the possibility of potential hazards and workplace accidents as garbage collectors and the risk of exposure to diseases that can be transmitted through waste, training, and demonstrations about the use of Personal Protective Equipment (PPE) when work and hand over a set of PPE tools to the scavengers. Community service activities carried out on 39 waste pickers in several TPS located in Kelurahan langkai city of Palangka Raya.
\end{abstract} (http://creativecommons.org/licenses/by-sa/4.0/). DOI: https://doi.org/10.33084/pengabdianmu.v5i3.1430

\section{PENDAHULUAN}

Pada Undang-Undang No 18 Tahun 2008 tentang

Pengelolaan Sampah, disebutkan sampah adalah sisa kegiatan sehari hari manusia atau proses alam yang berbentuk padat atau semi padat berupa zat organikatau anorganik bersifat dapat terurai atau tidak dapat terurai yang dianggap sudah tidak berguna lagi dan dibuang ke lingkungan, maka sampah yang sudah menumpuk di 
Tempat Penampungan Sampah harus segera diangkut ke Tempat Pemrosesan Akhir (TPA) (Kusminah, 2018; Seppina et al., 2017). Tempat Penampungan Sementara (TPS) adalah tempat sebelum sampah diangkut ke tempat pendaur ulangan, pengelolaan, dan/atau tempat pengelolaan sampah terpadu (Setiadi, 2015). Pemulung mengumpulkan sampah rumah tangga baik dari tempat sampah rumah warga atau TPS di sepanjang jalan atau di TPA (Sahwan \& Wahyono, 2002). Pemulung adalah orang yang bekerja mengambil barang-barang bekas atau sampah tertentu untuk proses daur ulang (Seppina et al., 2017).

Pemulung yang bekerja di TPS-TPS di wilayah kelurahan Langkai kota Palangka Raya, selain mengumpulkan plastik, logam dan kardus, mereka juga mengumpulkan makanan sisa untuk pakan ternak dan ada sebagian yang menjualnya. Berbagai jenis sampah ada di dalam TPS yang bercampur menjadi satu sehingga menimbulkan bau tidak sedap. Tentu saja jenis sampah yang mendominasi di TPS-TPS tersebut adalah sampah rumah tangga yang tidak menutup kemungkinan juga terdapat sampah Bahan Berbahaya dan Beracun (B3) (Malina et al., 2017).

Penelitian Iswanto et al. (2016) menyimpulkan bahwa jenis Sampah B3 rumah tangga yang banyak ditemukan adalah sampah elektronik (24,91\%), lampu listrik bekas $(18,08 \%)$ dan baterai bekas $(16,71 \%)$. Ketiga jenis sampah tersebut mengandung berbagai unsur logam berat seperti Cd, Pb, Hg, Cr, As, Ni, Co, Zn, Cu, Al, Mn, Li, Sb, dan Fe yang umumnya bersifat toksik, karsinogenik dan akumulatif yang dapat masuk ke dalam tubuh manusia secara langsung atau melalui rantai makanan. Pemaparan B3 dapat menyebabkan kerusakan pada berbagai jaringan/organ tubuh pada masyarakat sekitar tempat pembuangan, petugas sampah, pemulung, pengepul, pemanfaat dan pelaku daur ulang sampah B3 rumah tangga. Oleh karena itu, sampah B3 rumah tangga perlu dikelola sebagaimana mestinya sesuai dengan sifat dan karakteristiknya (Ichtiakhiri \& Sudarmaji, 2015).

Beberapa contoh sampah B3 yang dihasilkan di rumahtangga antara lain sampah dari baterai, lampu listrik, elektronik, kemasan pestisida, pemutih pakaian, pembersih lantai, cat, kaleng bertekanan (aerosol), kemasan bahan bakar, sisa obat-obatan (farmasi), termometer air raksa dan jarum suntik. Bahan-bahan yang terkandung di dalam sampah B3 memiliki sifat yang dapat menimbulkan gangguan keselamatan dan kesehatan manusia serta pencemaran lingkungan (Iswanto et al., 2016).

Meskipun belum terdapat data yang pasti adanya kecelakaan atau penyakit akibat kerja di TPS atau TPA, namun risiko adanya gangguan kesehatan atau penyebaran penyakit karena paparan berbagai jenis sampah sangat mungkin terjadi. Penyakit akibat kerja adalah penyakit yang disebabkan oleh pekerjaan, alat kerja, bahan, proses maupun lingkungan kerja, sehingga diperlukan Alat Pelindung Diri(APD) sebagai perangkat alat yang dipakai oleh tenaga kerja untuk melindungi dirinya terhadap kemungkinan adanya potensi bahaya serta kecelakaan kerja (Respati, 2016). Penggunaan APD sangat dianjurkan karena merupakan suatu upaya untuk menghindari paparan risiko bahaya disuatu tempat kerja. Menurut Sofia \& Kartini (2016), angka kesakitan pada pemulung tinggi, namun jarang terdeteksi dan tidak ada laporan dari pemulung karena rendahnya kemampuan terhadap akses pelayanan kesehatan. Menurut Coelho et al. (2016), para pemulung wanita yang mengumpulkan sampah terpapar pada kondisi kerja yang berbahaya dan memiliki potensi risiko gangguan kesehatan.

Menurut Sony dan Suyoto (2008), penyakit yang biasanya ditemukan pada pekerja yang berkontak dengan sampah diantaranya sebagai berikut: 
1. Infeksi Saluran Pernapasan Atas (ISPA) yang disebabkan oleh virus dan bakteri yang berasal dari sampah dan terbawa di dalam udara yang dihirup oleh manusia saat bernapas.

2. Alergi kulit: karena kontak dengan sampah ataupun dengan air yang tercemar disekitar lokasi kerja TPS/TPA. Ini sangat berkaitan dengan kondisi air yang digunakan, kebersihan diri, dan lingkungan kerja dan rumah.

3. Infeksi kulit, disebabkan oleh kutu air dan bias anya berkembang saat musim penghujan dan lingkungan sampah yang tergenang air.

4. Infeksi paru-paru, karena bakteri/virus dari sampah gejalanya adalah batuk-batuk terutama waktu malam, secara spesifik merupakan penyakit TBC yang dibuktikan dari hasil rontgen. Kondisi ini diperparah oleh status gizi yang rendah, yang ditandai dengan berat badan yang terus menurun.

5. Mencret-mencret (muntaber) karena salah makan makanan yang kotor, tidak mencuci tangan.

6. Pusing kepala, karena suhu yang tidak seimbang disebabkan oleh perbedaan suhu badan dan suhu lingkungan sekitar.

7. Sesak napas dan keracunan gas, tumpukan sampah akan mengalami proses penguraian yang menghasilkan gas diantaranya gas metan $\left(\mathrm{CH}_{4}\right)$. Setiap 1 ton sampah padat menghasilkan $50 \mathrm{~kg}$ gas metana. Gas lain yang juga dihasilkan oleh sampah ada $\mathrm{CO}_{2}$. Kedua gas ini merupakan penyumbang terbesar dari gas rumah kaca.

Tujuan kegiatan pengabdian kepada masyarakat ini untuk memberikan pendampingan dalam pengaplikasian APD dengan memberikan edukasi serta sosialisai tentang kemungkinan adanya potensi bahaya serta kecelakaan kerja sebagai pemulung sampah dan resiko terpapar penyakit yang dapat ditularkan melalui sampah, pelatihan dan demonstrasi tentang penggunaan APD saat bekerja serta penyerahan seperangkat alat APD kepada para pemulung untuk merangsang kesadaran para pemulung tentang pengguaan APD dalam rangka pengurangan resiko penularan penyakit melalui sampah di TPS. Selain itu kegiatan ini juga bertujuan untuk menanamkan kesadaran kepada diri pemulung terhadap pentingnya penggunaan APD saat bekerja. Kegiatan pelatihan dan demonstrasi dilakukan untuk melatih kemampuan para pemulung menggunakan serangkaian APD secara praktek sehingga terampil menggunakannya.

\section{METODOLOGI}

Kegiatan Pengabdian kepada Masyarakat ini dilaksanakan pada bulan September-oktober 2019. Kegiatan ini dilakukan di TPS-TPS yang berada di Kelurahan Langkai, Kota Palangka Raya, Kalimantan Tengah. Sasaran dalam kegiatan ini adalah para pemulung sampah yang ditemui di TPS-TPS saat kegiatan berlangsung. Metode pelaksanaan kegiatan PKM meliputi beberapa tahapan, yaitu persiapan, pelaksanaan, pendampingan dan evaluasi program. Solusi yang ditawarkan untuk menyelesaikan prioritas masalah pada pemulung di TPS di wilayah Kelurahan Langkai, Kota Palangka Raya adalah dengan melakukan edukasi dan sosialisasi tentang kemungkinan adanya potensi bahaya serta kecelakaan kerja sebagai pemulung sampah dan resiko terpapar penyakit yang dapat ditularkan melalui sampah, pelatihan dan demonstrasi tentang penggunaan APD saat bekerja, dan penyerahan seperangkat alat APD kepada para pemulung.

\section{HASIL DAN PEMBAHASAN}

Kegiatan yang dilakukan pada kegiatan pengabdian ini adalah sosialisasi dan praktek Penggunaan APD pada pemulung sampah di kelurahan langkai kota palangka 
raya. Kegiatan ini dilakukan disekitar 14 TPS dan 3 kontainer.

Tabel I. Daftar TPS di kelurahan langkai Kota Palangka Raya

\begin{tabular}{cl}
\hline No & \multicolumn{1}{c}{ Alamat TPS } \\
\hline 1 & TPS Jalan Marina Permai II \\
2 & TPS Jalan Nyai Enat \\
3 & TPS Jalan D.I Panjaitan (samping PU Provinsi) \\
4 & TPS Jalan Sudirman (Depan KPU Provinsi) \\
5 & TPS Jalan Suprapto (Depan PMI) \\
6 & TPS Jalan Patih Rumbih (samping RS Doris Sylvanus) \\
7 & TPS Jalan Patih Rumbih (Depan SDN Langkai 8) \\
8 & TPS Jalan Tendean \\
9 & TPS Jalan Katingan \\
10 & TPS Jalan C. Mihing \\
11 & TPS Jalan Nyai Balau \\
12 & TPS Jalan Junjung Buih \\
13 & TPS Komp. Bama Raya \\
14 & TPS Jalan Bhayangkara \\
\hline
\end{tabular}

Metode pelaksanaan kegiatan PKM meliputi beberapa tahapan, yaitu persiapan, pelaksanaan pendampingan dan evaluasi program. Tahap persiapan meliputi survey lapangan, wawancara, persiapan alat dan bahan. Survei lapangan, dilakukan dengan mendatangi tiap-tiap TPS di kelurahan langkai dimana para pemulung bekerja dan Wawancara, dilakukan terhadap para pemulung untuk menggali informasi pengetahuan awal para pemulung. Selain identitas, kegiatan ini dilakukan untuk menggali pengetahuan dan wawasan pemulung terhadap resiko penyakit menular dan kesadaran penggunaan APD.

Dari proses wawancara akan diperoleh informasi mengenai pemhamaman para pemulung tentang risiko penyebaran penyakit menular atau gangguan kesehatan melalui sampah dan penggunaan APD. Wawancara dilakukan dengan menggunakan instrumen angket. Dokumentasi kegiatan wawancara disajikan pada Gambar 1.

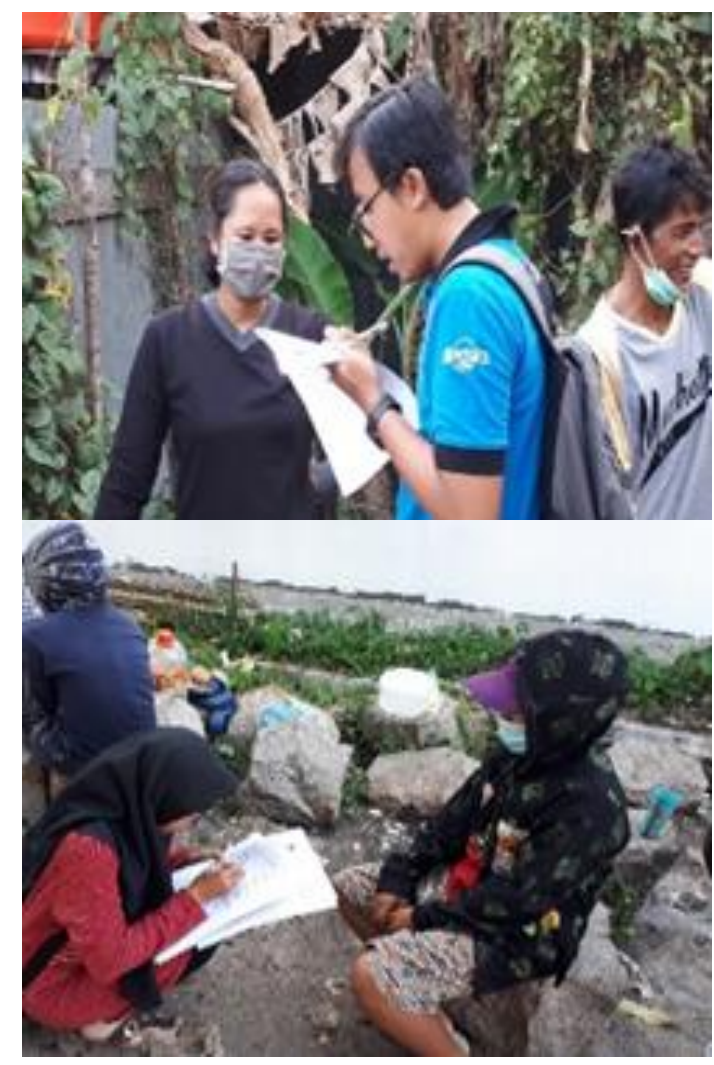

Gambar 1. Kegiatan wawancara pemulung di beberapa titik TPS

Berdasarkan pengisian angket melalui wawancara terhadap pemulung diperoleh hasil yang disajikan pada Gambar 2. Gambar 2 menunjukkan rendahnya penggunaan APD pada pemulung. Penggunaan APD yang paling rendah adalah penggunaan apron atau jaket pelindung. Sebanyak $92 \%$ pemulung tidak memakai APD jenis ini.

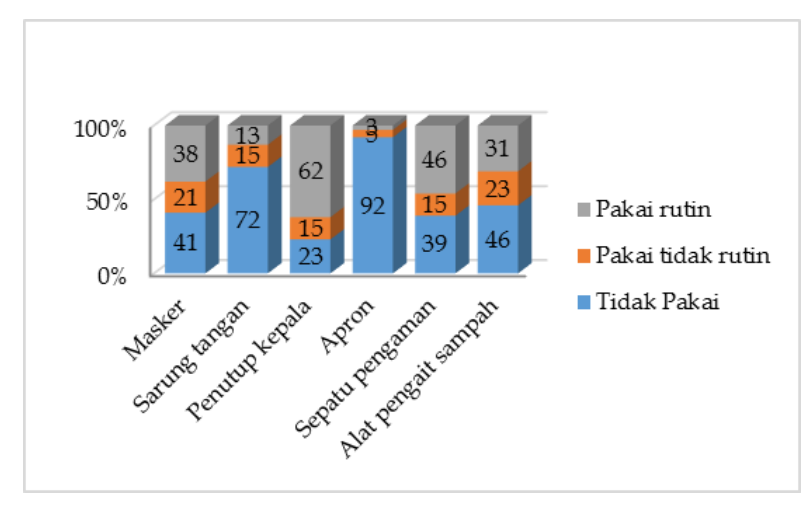

Gambar 2. Tingkat penggunaan APD oleh pemulung 
Hampir separuh pemulung tidak menggunakan masker, sarung tangan, apron, dan alat pengait sampah. Masker yang dipakai rutin oleh 38\% pemulung merupakan masker-sekali-pakai yang telah digunakan berulang-ulang sehingga tidak sesuai standar kesehatan dan keselamatan kerja (K3). Pemulung yang rutin menggunakan sarung tangan sebanyak $13 \%$, namun sarung tangan yang digunakan tidak sesuai standar, dimana sebagian besar menggunakan plastik/kresek yang menutupi permukaan tangan dan diikat menggunakan tali. Pemulung yang rutin menggunakan alat pengait sampah sebanyak $31 \%$, alat tersebut digunakan untuk mengais sampah sehingga sampah tidak bersentuhan langsung dengan tangan. Penggunaan rutin APD yang tinggi adalah penutup kepala yaitu sebanyak $62 \%$ dan sepatu pengaman sebanyak $46 \%$. Namun, sebagian pemulung yang menggunakan sepatu masih belum memakai sepatu boot.

Tahap pelaksanaan pendampingan meliputi edukasi dan sosialisasi, demonstrasi dan pemberian bantuan APD. Kegiatan edukasi dan sosialisasi dilakukan dengan cara memberikan pengetahuan kepada para pemulung melalui ceramah dan tanya jawab. Kegiatan ini dilakukan untuk memberikan pemahaman kepada para pemulung tentang jenis-jenis sampah, penyakit-penyakit yang bisa ditularkan melalui sampah, Jenis-jenis APD dan fungsinya, pentingnya penggunaan APD saat bekerja, dan pengurangan resiko penyebaran penyakit yang bisa menjangkit melalui sampah yang sering ada di TPS.

Resiko kecelakaan kerja ataupun penularan penyakit melalui sampah sangat rentan terjadi pada pemulung yang sering kontak dengan sampah. Penggunaan APD yang benar dapat menurunkan resiko-resiko tersebut. Kegiatan pelatihan dan demonstrasi penggunaan APD seperti ditunjukkan pada Gambar 3 dilakukan melalui pelatihan dan praktek langsung oleh tim dan para pemulung. Kegiatan ini untuk melatih para pemulung menggunakan APD dengan baik dan benar, sehingga dapat melindungi pemulung dari kecelakaan kerja atau penularan penyakit.

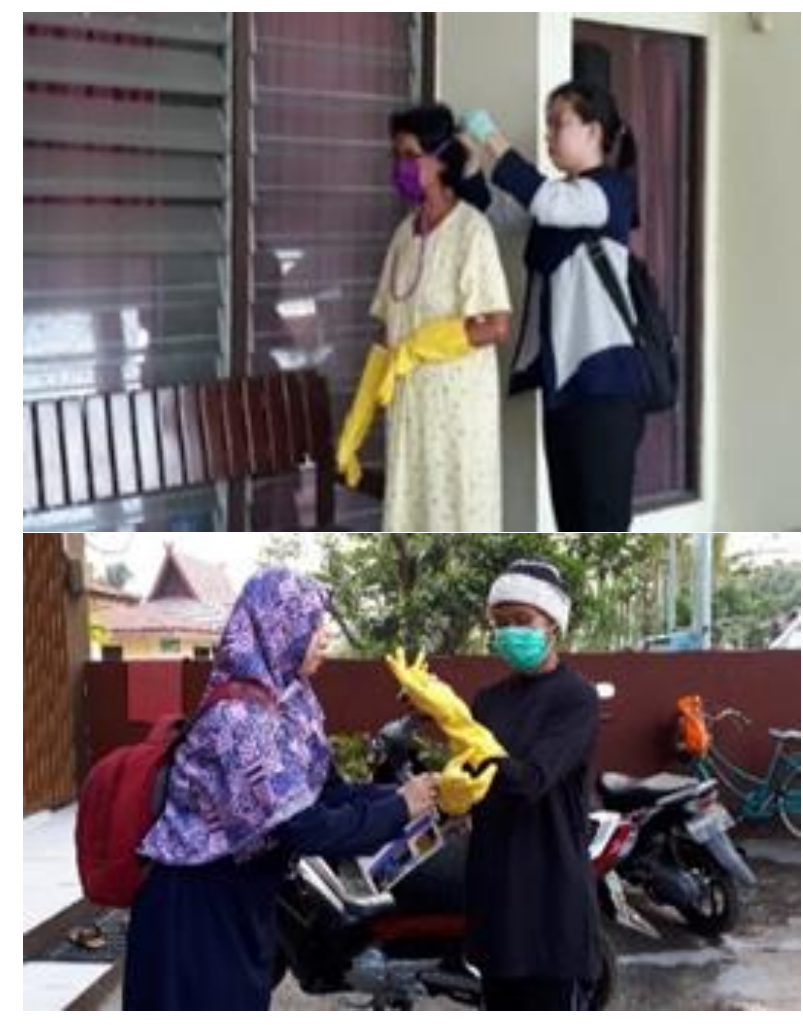

Gambar 3. Kegiatan pelatihan dan demonstrasi penggunaan APD kepada pemulung

Kegiatan selanjutnya penyerahan seperangkat alat APD kepada para pemulung, penyerahan dilakukan sebagai langkah awal terhadap upaya mengurangi bahaya sampah bagi kesehatan dan kecelakaan saat bekerja. Hal ini juga dilakukan untuk merangsang kesadaran para pemulung tentang penggunaan APD. Evaluasi dilakukan terhadap seluruh tahap dalam kegiatan PKM ini, mulai persiapan, wawancara/kuesioner, edukasi dan sosialisasi, pelatihan dan demonstrasi, serta pembagian APD kepada para pemulung.

\section{KESIMPULAN}

Kegiatan ini dilakukan kepada 39 pemulung yang tersebar di TPS-TPS yang berada di Kelurahan Langkai, 
Kota Palangka Raya. Kegiatan ini meliputi survei lapangan, wawancara, edukasi dan sosialisasi, pelatihan dan demonstrasi, serta penyerahan seperangkat APD. Edukasi dan sosialisasi tentang jenis-jenis sampah, penyakit yang ditularkan melalui sampah, APD dan fungsinya, pentingnya penggunaan APD untuk menurunkan resiko penularan penyakit melalui sampah. Pelatihan dan demonstrasi dalam penggunaan APD terhadap pemulung dalam upaya meningkatkan keterampilan pemulung dalam menggunakan APD dengan baik dan benar. Rangkaian kegiatan ini dapat meningkatkan wawasan pemulung terhadap bahaya penularan penyakit melalui sampah dan cara pencegahanya. Kegiatan pendampingan dalam penggunaan APD dapat dilanjutkan ke tahap pendampingan yang lebih lanjut agar dapat memantau keberlanjutan terhadap kesadaran para pemulung dalam menerapkan penggunaan APD saat bekerja dan untuk menjaga kesehatan mereka.

\section{REFERENSI}

Coelho, A.P.F., Beck, C.L.C., Fernandes, M.N.S., Freitas, N.Q., Prester, F.C., Tonel, J.Z. 2016. Women Waste Pickers: Living Conditions, Work, and Health. The Revista Gaúcha de Enfermagem. 37(3):57321. https://doi.org/10.1590/19831447.2016.03.57321

Ichtiakhiri, T.H., Sudarmaji. 2015. Pengelolaan Limbah B3 Dan Keluhan Kesehatan Pekerja di PT. INKA (Persero) Kota Madiun. Jurnal Kesehatan Lingkungan. $\quad$ 8(1):118-127. http://dx.doi.org/10.20473/jkl.v8i1.2015.118127

Iswanto, Sudarmadji, Wahyuni, E.T., Sutomo, A.H. 2016. Timbulan Sampah B3 Rumahtangga Dan Potensi Dampak Kesehatan Lingkungan Di Kabupaten Sleman, Yogyakarta. Jurnal Manusia dan Lingkungan. 23(2):179-188. https://doi.org/10.22146/jml.18789

Kusminah, I.L. 2018. Penyuluhan 4R (Reduce, Reuse, Recycle, Replace) dan Kegunaan Bank Sampah Sebagai Langkah Menciptakan
Lingkungan Yang Bersih Dan Ekonomis Di Desa Mojowuku Kab. Gresik. JPM17: Jurnal Pengabdian Masyarakat. 3(1):22-28. https://doi.org/10.30996/jpm17.v3i01.1165

Malina, A.C., Suhasman, Muchtar, A., Sulfahri. 2017. Kajian Lingkungan Tempat Pemilahan Sampah Di Kota Makassar. Jurnal Inovasi Dan Pelayanan Publik Makassar. 1(1):14-27

Respati, R. 2016. Analisis K3 pada Sistem Pengangkutan Sampah Rumah Tangga di Jalan Garuda Kota Palangka Raya. Media Imiah Teknik Lingkungan (MITL). 1(2):40-48. https://doi.org/10.33084/mitl.v1i2.145

Sahwan, F.L., Wahyono, S. 2002. Pengelolaan Sampah Permukiman Berbasis Masyarakat. Jurnal Teknologi Lingkungan. 3(1):7-12. https://doi.org/10.29122/jtl.v3i1.229

Seppina, D.S., Hilal, N., Rudijanto, H.I.W. 2017. Upaya Pemulung Dalam Mencegah Risiko Gangguan Kesehatan Di Tpa Banjaran Kecamatan Bojongsari Kabupaten Purbalingga Tahun 2017. LINK. 13(1):14-19. https://doi.org/10.31983/link.v13i1.2589

Setiadi, A. 2015. Studi Pengelolaan Sampah Berbasis Komunitas pada Kawasan Permukiman Perkotaan di Yogyakarta. Jurnal Wilayah dan Lingkungan. 3(1):27-38. https://doi.org/10.14710/jw1.3.1.27-38

Sofia, S., Kartini, K. 2016. Hubungan Lama Memulung Dan Penggunaan Alat Pelindung Diri Dengan Kejadian Penyakit Di Tempat Pembuangan Akhir Sampah. AcTion: Aceh Nutrition Journal. 1(1):47-51. http://dx.doi.org/10.30867/action.v1i1.8

Sony, T.B.L., Suyoto, B. 2008. Pemulung Sang Pelopor 3R Sampah. Jakarta: Pidus Zero Waste Indonesia. 